\title{
Indonesian EFL teachers' content conceptualization and course organization: A portray of text-based teaching
}

\author{
Anita Triastuti ${ }^{1 *}$ and Mehdi Riazi ${ }^{2}$ \\ ${ }^{1}$ English Language Education Department, Faculty of Languages and Arts, Universitas Negeri Yogyakarta, \\ Jl. Colombo No 1, Karang Malang, Depok, Sleman, D.I. Yogyakarta 55281, Indonesia \\ ${ }^{2}$ Department of Linguistics, Faculty of Human Sciences, Macquarie University, North Ryde, NSW 2109 , Australia
}

\begin{abstract}
Frequent changes of Indonesian English as a Foreign Language (EFL) national curriculum have transformed EFL teachers' role from that of serving merely as curriculum transmitters into curriculum adapters. Accordingly, this study intended to explore how a group of Indonesian EFL teachers conceptualize content and course organization as guided by the Indonesian national EFL curriculum. A qualitative multiple-case study (Miles, Huberman, \& Saldana, 2014; Stake, 2006; Yin, 2014) was employed to collect and analyze data. Purposive within - and cross-case sampling techniques were used to select six EFL teachers; three experienced and three inexperienced teachers of public junior high schools in the Special Territory of Yogyakarta, Indonesia. Sources of data included instructional curriculum design assessments and pre-lesson semi-structured interviews. Analysis of the data revealed these teachers' content conceptualization focuses on blending texts and English language skills that characterize the implementation of text-based teaching in the Indonesian EFL context. Results of the data analysis for course organization showed teachers' insufficient understanding of the selected organizing principles for teaching texts. Such understanding led to inconsistency between theory and practice. The findings of the study shed light on a misconception about implementing text-based teaching. Implications of the study address the need to equip Indonesian EFL teachers with both the conceptual and practical knowledge of implementing the methodology of text-based teaching.
\end{abstract}

Keywords: EFL curriculum; content conceptualization; course organization; instructional curriculum design; text-based teaching

\begin{tabular}{|c|c|}
\hline $\begin{array}{l}\text { First Received: } \\
\text { 15 July } 2019 \\
\text { Final Proof Received: } \\
8 \text { January } 2020 \\
\end{array}$ & $\begin{array}{c}\text { Accepted: } \\
\text { 6 December } 2019 \\
\text { Published: } \\
\text { 31 January 2020 } \\
\end{array}$ \\
\hline $\begin{array}{l}\text { How to cite (in APA style): } \\
\text { Trias tuti, A. \& Riazi, M. (2020). Indonesian EFL teachers } \\
\text { course organization: A portray of text-based teachin } \\
\text { Linguistics, } 9,526-535 \text {. doi: } 10.17509 / \text { ijal.v9i3.23202 }\end{array}$ & $\begin{array}{l}\text { tent conceptualization and } \\
\text { lonesian Journal of Applied }\end{array}$ \\
\hline
\end{tabular}

\section{INTRODUCTION}

Rooted in Australian genre theory (Hyland, 2007; Martin, 2009, 2013; Rose, 2011), genre-based pedagogy has been widely explored to particularly develop learners' literacy towards various academic genres. Manifested into text-based teaching, learners are equipped with a critical awareness of and access to various genres (Burns, 2012; Frankel, 2013). Through text-based teaching methodology, learners' will be engaged in a variety of texts so that they can ultimately take the ownership of their own learning by producing their own texts in what is so-called the independent construction stage (Burns, 2012; Feez, 1999; Feez \& Joyce, 1998; Hammond \& Derewianka, 2001; Martin, 1999).

Research on English as a second language (ESL) and English as a foreign language (EFL) genre-based pedagogy have confirmed the effectiveness of this approach pedagogy to help learners to be capable of reading, writing, and speaking a particular genre (e.g., Albino, 2017; Burns, Joyce, \& Gollin, 1996; Emilia \& Hamied, 2015; Liang, 2015; Megawati \&

\footnotetext{
* Corresponding Author

Email: anitatria@uny.ac.id
} 
Anugerahwati, 2012; Ramos, 2015; Ranker, 2009; Rivera, 2012; Thai, 2009; Yasuda, 2011). This line of research has reported students' improvement of their ability to construct their own texts after experiencing text-based learning activities. The approach entails a thorough and overt instruction in a sequence of scaffolded stages (Feez \& Joyce, 1998). The overall devised activities for the stages of the teaching and learning cycle comprise teachers' systematic assistance for students to understand the features of the given texts and to finally create their own texts.

The innovation of genre-based tasks, for example, emerges in response to students' learning needs in learning specific content (English for Specific Purposes or ESP) (Albino, 2017). Through ESP, students learn how to construct real-life genres (Yasuda, 2011). In addition to implementing the teaching and learning cycle, such an approach uses a particular stage called a situated practice for engaging students in multifaceted literacy practices (Ranker, 2009), and applies genrebased tasks, which combine genre-based and task-based instruction (Albino, 2017; Yasuda, 2011). Genre-based pedagogy has been widely adopted in instruction and is widely researched in many parts of the world including Southeast Asian countries such as Indonesia, Singapore, Vietnam, Hongkong, and Japan; European countries such as Germany, France, Denmark, Sweden; and South American countries such as Brazil and Argentina (Emilia, Christie, \& Humphrey, 2012 cited in Emilia \& Hamied, 2015). In the Indonesian EFL context, genrebased pedagogy is used at schools as guided by the national EFL curriculum (see, e.g., Hamzah \& Rozimela, 2018; Megawati \& Anugerahwati, 2012). Notwithstanding the merits of genre-based pedagogy, it has created some challenges for Indonesian EFL teachers of how best to put genre-based pedagogy into practice as directed by the Indonesian EFL national curriculum. Despite the growing number of studies on genre-based pedagogy, few studies have discussed the challenges teachers have encountered in developing genre-based pedagogy within their own contexts. It is, therefore, imperative to study how socio-educational context (Graves, 2008) underlying the enactment of genre-based pedagogy characterizes its implementation.

This paper reports part of a larger-scale study on Indonesian EFL teachers' conceptualizations of pedagogical content knowledge (PCK) (Shulman, 1987) in designing their instructional practice. The paper explores Indonesian EFL teachers' challenges in implementing text-based teaching within the framework of the Indonesian EFL curriculum called the 2006 School-based Curriculum (SBC). The report focuses on teachers' conceptualization of the mixed-content categories of their text-based instruction and organizing their instruction based on the organizing principles they adopted. The paper reports on the implementation of genre-based pedagogy when the Indonesian EFL curriculum was at a transition period, in which the 2006 SBC was gradually revised into the 2013 Curriculum.

\section{Text-based teaching}

Rooted in a genre-based approach, text-based teaching was initiated in Australia as part of the national Adult Migrant Education Program (AMEP) curriculum framework (Feez, 1999). Transcending the aim of genre-based pedagogy, text-based teaching is, therefore, intended to develop students' knowledge and skills to comprehend and engage themselves with the use of reallife texts (Burns, 2012). Students in text-based instruction are introduced to a variety of texts from which they learn texts as "stretches of unified, meaningful, and purposeful natural language" (Feez, 1999, p. 11). These stretches of language constitute specific linguistic features and structures that operate within certain contexts (Burns, 2012; Feez \& Joyce, 1998). Thus, any understanding or interpretation assigned to text is attached to its context and text semantics and function (Halliday, 1975). The basic unit through which meaning is negotiated is, therefore, a unified whole and not limited to size, length, or form of language (Feez \& Joyce, 1998).

In summary, the text refers to the various types of language people use in their daily communication, as Halliday (1975) describes in the following:

... the language people produce and react to, what they say and write, and read and listen to, in the course of daily life. ... The term covers both speech and writing ... it may be language in action, conversation, telephone talk, debate ... public notices ... intimate monologue or any thing else (p. 123).

Departing from the concept of text in genre-based pedagogy, in text-based teaching, the use of texts as they are found and used in real life is, therefore, the central aspect of the instruction (Burns, 2012). In this sense, texts are used as the starting point to develop a syllabus, conceptualize content and design activities, plan assessment activities, and determine the role of teachers (Burns, 2012). The design and implementation of text-based teaching address several details in relation to its methodology, text authenticity, and scaffolding, which includes the nature and types of activities as well as the nature of assessment activities (Burns, 2012; Feez, 1999; Feez \& Joyce, 1998). The following paragraphs present such details.

At the methodology level, text-based teaching regulates a system for coherently selecting, sequencing, and presenting mixed-content categories for a learning cycle. This cycle, which was derived and adapted from genre-based pedagogy, is particularly relevant for enacting text-based instruction focusing on literacy teaching (Feez, 1999; Frankel, 2013; Hyland, 2007; Martin, 2013). However, some instructional practices have used the text-based methodology for teaching spoken exchanges (e.g., Burns, Joyce, \& Gollin, 1996; Rivera, 2012; Thai, 2009). The system of the text-based teaching and learning cycle offers a dynamic approach that enables teachers to start teaching from different entry stages of the cycle depending on students' learning needs, develop the instruction from any content 
category, and approach it backwards or forwards in the cycle (Feez, 1999; Feez \& Joyce, 1998).

The essential characteristic of text-based teaching, which puts its emphasis on the use of authentic texts, requires teachers to measure the degree of authenticity presented in their given texts. This raises a challenge for teachers to have sufficient skills and knowledge to judge the degree of text authenticity. As Mishan (2005) concludes, to be authentic, a text has to reflect a specific communication purpose in its social context. Therefore, the authenticity of a text lies in its meaning in its context. For this reason, it is argued that, when authentic texts are used in language learning, their authenticity is difficult to attain (Morrow, 1977 cited in Mishan, 2005; Widdowson, 1998). This is because language teaching cannot reproduce absolute authenticity in the texts (Morrow, 1977 cited in Mishan, 2005) or cannot replicate the reality embedded in the texts (Widdowson, 1998). In line with this argument, Burns (2012) also states that analyzing text authenticity is a difficult task for teachers. In presenting texts, teachers may be trapped in the use of "trivial examples of daily survival communication in contrast to more complex, hybrid, or ideologically charged texts ..." (Burns, 2012, p. 146), or in text simplification that leads to "a distortion of natural language" (McDonough \& Shaw, 2003, p. 82). The challenge resulting from the demand to use authentic texts in text-based teaching is also experienced by ESL EFL learners. As revealed in the long-standing debate on text authenticity in materials development (Tomlinson, 2012), giving authentic texts to learners, potentially invokes problems for them. One of the arguments in favor of learners states that learners may find authentic texts more unattainable than simplified texts (Day, 2003). In textbased teaching, teachers are, consequently, required to provide scaffolding for their learners.

Literally, scaffolding is described as temporary yet important assistance to help a child construct his/ her own foundation to successfully do a task by himself/ herself (Gibbons, 2015). In a classroom setting, 'scaffolding' was used to describe the role of teachers in supporting students by providing "explicit knowledge and guided practice" to assist students in moving forward through their zone of proximal development (Feez \& Joyce, 1998, p. 27). Thus, as Gibbons (2015, p. 16) states, scaffolding is not a general help; it is a particular temporary help that is intended to assist learners in acquiring new skills and knowledge to do a learning task independently. In text-based instruction, teachers' scaffolding, therefore, represents teachers' expert guidance for keeping track of learners' learning progress at various points in their learning development (Burns, 2012).

The teaching cycle in text-based teaching represents a series of scaffolded "developmental steps" (Feez \& Joyce, 1998, p. 34) that assist students in gaining success in using texts (Burns, 2012; Feez \& Joyce, 1998; Hammond \& Derewianka, 2001). The entire designed activities for each cycle reflect teachers' step-by-step guide for students, in order for students to finally obtain the mastery of learning by producing their own texts in the independent construction stage (Feez, 1999; Feez \& Joyce, 1998; Martin, 1999). Teachers' scaffolding starts from the first stage, that is, building the context or building knowledge of field or deconstruction, in which teachers take the full lead in guiding students to become familiar with the target text type they are going to learn. In this stage, activities can be directed to assisting students in investigating the socio-cultural context underlying the text and in eliciting relevant vocabulary and facilitate students to investigate particular topics incorporated in the texts (Derewianka, 2003). The second stage is modeling the text, in which the text exploration is done to instill the text structure and linguistic features to students. In the next stage of joint construction, teachers start to collaborate with students in constructing the target text. Therefore, the nature of activities in this stage is collaborative. Finally, in the last stage of independent construction, it is the time for teachers to restrain their scaffolding and let students personally use and produce their texts based on the previously given and explored models.

Against the above backdrop, this study intended to investigate how two groups of EFL teachers (experienced and inexperienced) in an Indonesian context would conceptualize their instructional content and organize their text-based instruction as required by the Indonesian EFL curriculum. In particular, the study intended to find answers to the following research question:

1. How do teachers transform their understanding of content into effective instructional curriculum design within the particular socioeducational context?

\section{METHOD}

This study employed a multiple-case study with a within- and cross-case design (Miles, Huberman, \& Saldana, 2014; Stake, 2006; Yin, 2014). The following sub-sections present the details of the study.

\section{Research participants}

Six EFL teachers of public junior high schools (PJHS) in the Special Territory of Yogyakarta, Indonesia, provided data for the study. Purposive sampling technique was employed to recruit these six teachers, including three experienced and three inexperienced EFL teachers. The experienced teachers were certified teachers who had passed the National Teacher Certification Program (NTCP) and had more than five years of teaching experience. On the contrary, the inexperienced teachers were uncertified teachers who were not yet promoted to take the NTCP and had less than five years of teaching experience. The six teachers taught English at six different schools in three regencies of Kulonprogo, Bantul, Gunungkidul, and one municipality of Yogyakarta. Table 1 below presents the profile of the teacher participants using pseudonyms. 
Table 1. The profile of the teacher participants

\begin{tabular}{lcc}
\hline \multicolumn{1}{c}{ Teachers } & $\begin{array}{c}\text { Years of Experience (Counted up to } \\
\text { December 2013) }\end{array}$ & Certification S tatus \\
\hline Experienced Teachers & 16 years 10 months & Certified in 2010 \\
Meri & 16 years 11 months & Certified in 2009 \\
Susan & 24 years 9 months & Certified in 2009 \\
Sisilia & & \\
Inexperienced Teachers & & Non-certified \\
Etta & 3 years 11 months & Non-certified \\
Nuri & 2 years 11 months & Non-certified \\
Tria & 1 year 5 months & \\
\hline
\end{tabular}

\section{Data collection instruments and procedures}

Two instruments comprising the instructional curriculum design assessment sheets and pre-lesson semi-structured interviews were used to collect the required data from teachers. The assessment sheet was a scale with descriptors to assess how teachers conceptualized PCK and organized the course. The semi-structured interview included thirteen recall questions so that teachers could recall and explain the process of planning their instruction. Two of the questions were dedicated to exploring the teachers' content conceptualization and course organization.

The teachers' instructional curriculum design assessments were done over the teachers' lesson plans and the supporting annexes. During the data collection, the researcher attempted to grasp the extent of the effectiveness of the teachers' instructional curriculum design by referring to the rubric of the instructional curriculum design assessment that had been developed. Prior to the data collection, the researcher made efforts to make herself familiar with the rubric so as to ease the researcher in making a preliminary assessment of the teachers' instructional curriculum design. Hence, the teachers' content conceptualization and course organization as represented in their instructional curriculum design documents, in the form of lesson plans, were assessed in terms of how the teachers articulated the content categories of skills and texts, and how they organized their lessons by means of particular organizing principles to form a coherent instruction.

The pre-lesson semi-structured interviews were conducted both in Bahasa Indonesia and English. The teachers were allowed to switch their English into Bahasa Indonesia when answering the questions. Each interview lasted for 45-60 minutes and was managed to be reasonably similar in length across the six cases and to explore similar amounts of information from all the six cases for balancing within- and cross-case comparisons (Cohen, Manion, \& Morris on, 2007).

\section{Data analysis}

Analysis of the teachers' instructional curriculum design assessments was done manually by developing matrices (Patton, 2002; Saldana, 2013; Stake, 2006; Yin, 2014). These matrices included the teachers' evidence of their PCK conceptualizations in the processes of conceptualizing content and organizing the course. Emerging patterns in the teachers' conceptualizations of PCK in each process were identified.

The pre-lesson interviews were coded and analyzed by means of the NVivo 10 program. The selected units of meaning in relation to the teachers' content conceptualization and course organization were segmented and labeled (Miles, Huberman, \& Saldana, 2014). The emerging patterns of the teachers' content conceptualization and course organization were then extracted from the assessment matrices and interviews. Subsequently, these patterns were used for within- and cross-case comparisons of the teachers' content conceptualization and course organization decisions.

\section{RESULTS AND DISCUSSION \\ Within- and cross-case patterns of content conceptualization}

Analysis of the data indicated an intricate process of transforming the content categories of skills and texts into relevant learning activities by teachers. This was done so that students could develop their micro and macro skills of the English language, and comprehend and produce texts. The cross-case comparisons showed patterns of teachers' conceptualizations of content categorization and those of blending skills and texts as the main content categories of text-based teaching in the Indonesian EFL context. Table 2 below presents the cross-case comparis ons of the teachers' content focuses, specifying their choices of content categories. As shown in the table, all the six teachers conceptualized the same content categories, except that only one experienced teacher (Susan) included sociolinguistic skills.

As shown in Table 2, the three content focuses included language, learning and learners, and social context. The language focus represented categories of "skills" and "texts." The teachers developed learning activities for developing students' micro and macro skills, while they attempted to select appropriate texts with linguistic and functional features so that students could work on and subsequently construct their own texts. At the same time, the teachers developed learning activities that integrated character building (developing moral values) and interpersonal skills. Both the experienced and inexperienced teachers revealed the same pattern of integration for moral values. They planned to promote several selected values using particular learning activities. The values were selected 
from the list of values determined by the Regency Panel of English Subject Teachers (MGMP-Musyawarah Guru Mata Pelajaran). In the case of the experienced teachers, Meri and Sisilia demonstrated such integration. For example, to develop the values of being responsible and cooperative, Meri planned such activities as discussion and group work. In the same vein, Sisilia admitted that, by assigning group work, she would be able to observe how the expected values were demonstrated by her students when carrying out the activity and participating in their groups. The following two quotes from these two teachers are indicative of such activities.

Table 2. The cross-case comparis on of content conceptualization and focuses

\begin{tabular}{ll}
\hline Content Focuses & Content Categories \\
\hline Language & Skills: macro \& micro skills \\
& Texts: linguistic features (vocabulary, expressions, grammar, verbs, and sentence patterns), generic \\
& structure (organization of text), functions, situations, tasks, communicative competence, and \\
& topics/themes, the social purpose of the text
\end{tabular}

Learning \& Learners Character building \& interpersonal skills

Social Context

Sociolinguistic skills (in the case of Susan)

(unshared content focus)

In the teaching and learning process, for example, hmm ... the character of being cooperative ... the students are divided into some groups ... when assigned to group work, they have to cooperate. That's why I assign them to work in groups to teach them how to cooperate with others. (Meri, Pre- Lesson Interview, Meeting 3)

I see from their working in a group, for example, how they work in a group. Do they work individually or do they cooperate with their friends, and how do they answer the questions? Do they answer logically, critically something like that? (Sisilia, Pre-Lesson Interview, Meeting 2)

The only content focus that was not shared withinand cross-cases is the focus on the social context. Only Susan, one of the experienced teachers, incorporated the continuum of politeness within the variety of expressions for a communication exchange in a restaurant setting for teaching transactional and interpersonal texts which involved the expressions of asking for and giving/ declining things, and offering, accepting/ declining things.

Oya, jadi, (Yeah, so) for example, today I will teach offering something. So, I will include good manners. So, I will ... well ... force students to use this and act it out in good way, in good manner how to offering something. So, I choose the situations, situations of the dialogues, the conversations so that students will be able to demonstrate oh this is the way to say in good way in this situation, to which people I could talk about. So, for example, in the restaurant of course you have to use good manner in expression. You have to be selective, for example, you use 'could' instead of 'can'. (Susan, PreLesson Interview, Meeting 1)

In terms of blending skills and texts, the teachers' content conceptualization portrays the patterns of integration in which skills and texts are blended for developing students' micro and macro language skills. The blend of skills and texts forms several patterns of teaching texts, while particularly emphasizing the development of students' micro and macro skills. The common patterns of the within-case comparison from each of the two groups of teachers yielded two main different patterns. These two patterns were: (1) the blend within a single skill focus, and (2) the blend within the integration of skills. The first pattern blends skills and texts in the receptive skills of listening and reading. This pattern was demonstrated by two experienced teachers (Meri and Sisilia) mostly when they conceptualized the content of skills and texts, within the teaching of reading and listening, and that of particular text types. Such a pattern was particularly intended to focus on either of those receptive skills. Using this blending pattern, Meri and Sisilia transformed the content categories of skills and texts into learning activities to develop students' micro and macro skills, and help them explore the linguistic features of the target texts, and comprehend the texts. Figure 1 illustrates this blending pattern.

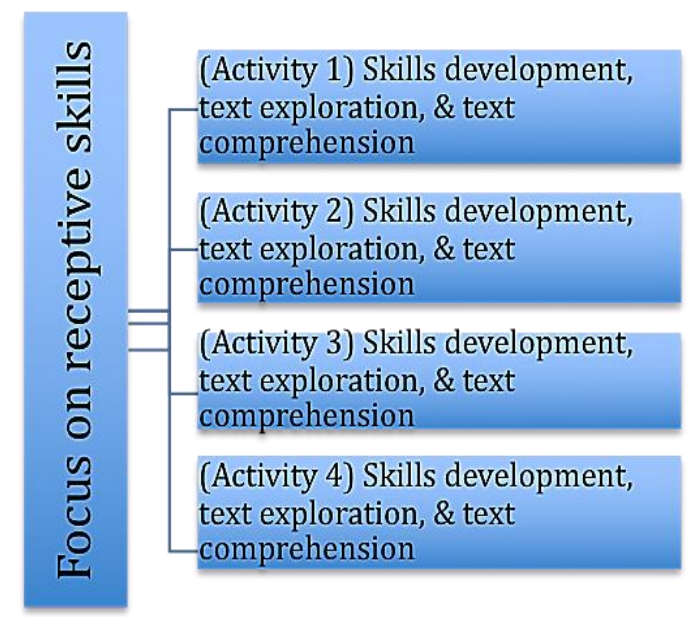

Figure 1. The blend of skills and texts within a single receptive skill focus (listening or reading)

Susan, however, was the only experienced teacher who demonstrated the second pattern, which was mostly conceptualized by the inexperienced teachers. This pattern blends the content of skills and texts within such 
integration of skills as reading-writing skills and listening-speaking skills.

Two patterns of integration were demonstrated by the inexperienced teachers for the second blending pattern. The first pattern of integration represented a layer of integration within different single skill focuses on a series of several lessons. Yet, the single skill focus in each lesson was the continuation of the previously developed skill. Etta, for example, showed the integration of reading-writing skills, while Nuri followed an integration of listening-speaking skills for their entire teaching sessions. Tria integrated a series of integration, which consisted of listening-writing and reading-writing skills in her teaching sessions. Such a series of integration projected the receptive skills as the bases or inputs for developing the target productive skills. Therefore, the learning activities of the receptive skills focus were designed for improving the target macro and micro skills, and exploring and comprehending the target texts. Then, within the productive skills focus, the learning activities for skills development and text exploration were strengthened so as to enable students to finally produce the target text types. This first pattern of integration is depicted in Figure 2.

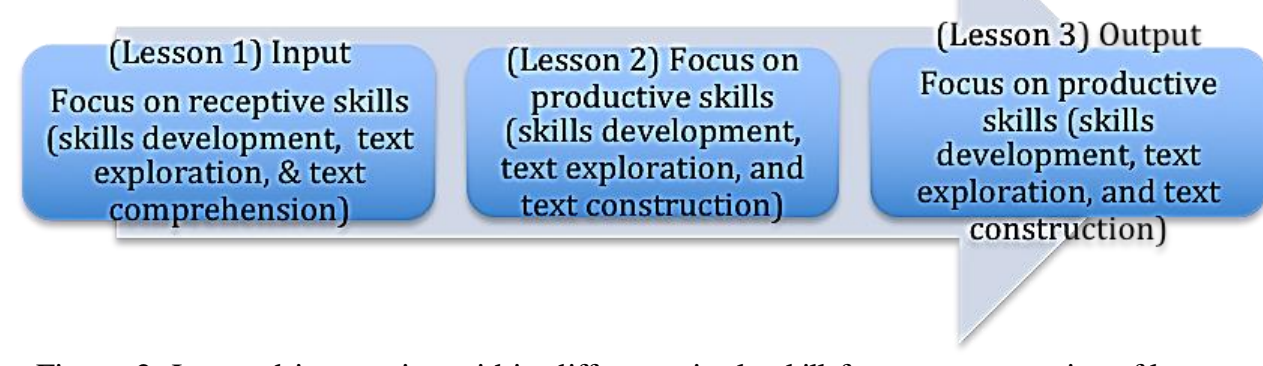

Figure 2. Layered integration within different single skill focuses on a series of lessons

The second pattern of integration was the integration within the strand of a lesson (Graves, 2000), as shown in Nuri's integration for her second and third teaching sessions and Tria's integration for her second teaching session. This pattern of integration divides a single lesson into two strands of skill focus, in which the division of the receptive skills as the input for the following productive skills was blended in one single lesson. The productive skills become the primary skill focus in this pattern of integration. The integration within the strand of a lesson is illustrated in Figure 3.

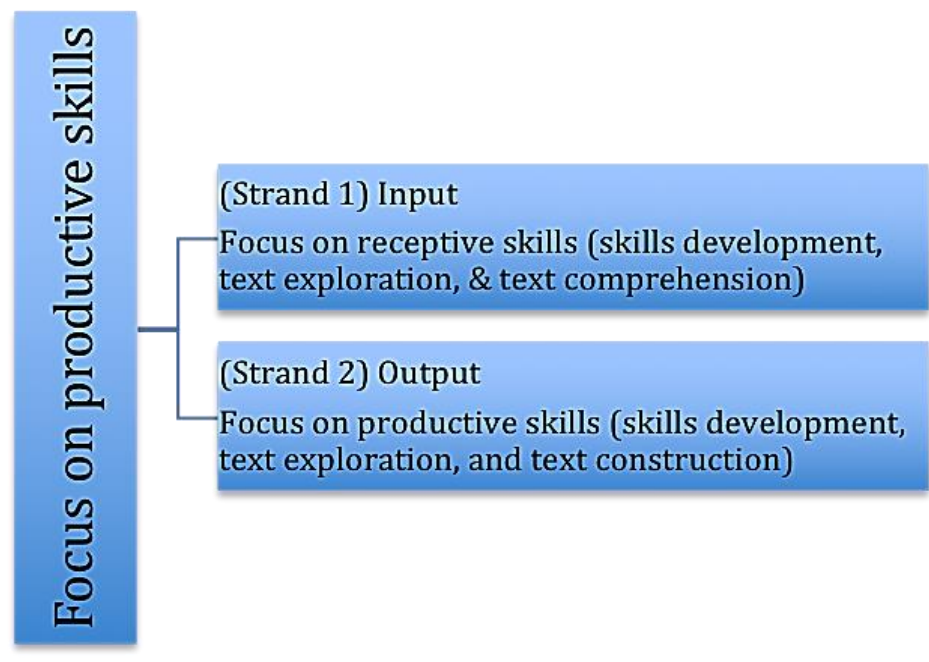

Figure 3. Layered integration within the strand of a single lesson

To sum up, in blending skills and texts, two experienced teachers tended to do so within the teaching of a single receptive skill focus. One case from this group, however, conceptualized the blend of skills and texts within the integration of skills, following the two integration patterns shared by the inexperienced teachers. Reflecting back to the elaborated patterns as demonstrated by both of the groups of teachers, the inexperienced teachers were braver in blending skills and texts within particular integrations of skills.

\section{Within- and cross-case patterns of course organization}

Several findings were identified from the cross-case comparis on of the teachers' conceptualizations of PCK in organizing their instruction. The first merged finding was the inappropriate adoption of the chosen organizing 
principles, including the prescribed organizing principle of Exploration, Elaboration, and Confirmation (EEC) as mandated by the 2006 School-based Curriculum (SBC). This prescribed EEC was applied in Indonesia when the research was conducted. The teachers' pedagogical concern for using this prescribed principle was more influenced by administrative requirements than by their understanding of the compatibility of the characteristics of this organizing principle with their instruction, as confirmed, for example, by Sisilia and Tria below.

Yes, because the MGMP has determined so ... in the trainings the school supervisor also taught us to use the EEC stages ... yeah I previously implemented BKOF ... now I have used this (the EEC stages) ... y eah I think the stages are just the same. (Sisilia, Pre-Lesson Interview, Meeting 4)

I don't know whether the four stages and the principles of $E E K$ itu (the EEC) can go together or not. But, from the lesson plans that I see from my friends, their lesson plans have been supervised by the supervisor. Some of them have the same with this kind of thing. They put the four stages here and the principle there. The last time I went to $M G M P$, the lesson study, I was the one that should plan to review it and next time I will have to do (it). There they, the $M G M P$ teachers, told me to put $E E K$ (the EEC). (Tria, Pre-Lesson Interview, Meeting 1)

In the case of the experienced teachers, two teachers, Sisilia and Susan, explicitly used and stated this prescribed organizing principle in their lesson plans, and the other teacher, Meri, adopted the textbased teaching and learning cycle while managing to put this cycle alongside the prescribed organizing principle in her lesson plans.

In the case of the inexperienced teachers, the explicit adoption of the prescribed organizing stages of EEC was only done by Etta, while the other teacher, Tria, made a similar attempt to Meri's. Tria stated that she adopted the organizing principles side by side with the stages of EEC to satisfy the administrative requirement she had to deal with. All three inexperienced teachers admitted that they had insufficient understanding of the prescribed organizing stages of EEC. The inexperienced teachers were also shown to adopt other organizing principles. Nuri employed the pre-, while-/ whilst-, and post-speaking/ listening stages for all her teaching sessions. Tria planned to apply the text-based teaching and learning cycle for teaching receptive skills (listening and reading) in her first and third teaching sessions and the productive skill (writing) in her second teaching session. Tria also adopted the stages of Presentation, Practice, and Production (PPP) for her fourth observed teaching session. The adoption of these organizing principles is also not pedagogically grounded in the substantial concern for why such stages are effective and relevant for organizing their instruction to enhance student learning. Tria and Nuri reasoned that the PPP stages and the pre-, while-/ whilst-, and post-speaking/ listening stages they adopted were relatively simpler than the text-based teaching and learning cycle.

\author{
... First, I haven't really comprehended the EEC, and for \\ the BKOF, it needs four stages. That one is only 3 \\ stages, so for me it is simpler. (Nuri, Pre-Lesson \\ Interview, Meeting 2)
}

Besides, in the case of Tria, she reasoned that the PPP stages enabled her to present the model text of birthday invitation from the beginning, whereas, in adopting the text-based teaching and learning cycle, Tria simply clarified that this cycle was suitable for teaching texts.

... . If I use (the teaching method) the genre-based approach, I will follow the 4 stages in it. But here, I use the PPP (presentation, practice, production method), so the main flow of the activities is similar but is not exactly the same. But the flow of activities from presenting, practicing, and producing are almost the same because finally, we come to Activity 5, which is the final task and is assessed for individual work today. Here I want to say that these five activities flow from an activity that (is) intended for classical work, and then design for group or pair work and then finally to individual work. (Tria, Pre-Lesson Interview, Meeting 4)

The second merged finding is that both the experienced and inexperienced teachers' conceptualizations of PCK in organizing their instruction showed some inconsistencies between theories and practice. The inconsistencies were shown in the ways the teachers' designed activities were incompatible with the characteristics of the organizing principles, as exemplified in the cases of Meri from the experienced teachers group, and Tria, from that of the inexperienced teachers group.

In the case of Tria, for example, the inconsistency was shown when the characteristic of the PPP stages, as a variety of Audiolingualism (Harmer, 2007; Spratt Pulverness, \& Williams, 2005), was used for organizing Tria's writing class to explore birthday invitation text. Tria's writing instruction in her fourth observed teaching session could have been more appropriately organized by means of the text-based teaching cycle for two reasons. Firstly, referring back to the characteristic of the text-based teaching methodology, the text-based teaching and learning cycle was particularly designed for literacy teaching (Feez, 1999). Secondly, the design of Tria's activities had demonstrated a certain degree of compatibility with the characteristics of the stages in the text-based teaching and learning cycle. As shown in Tria's prepared activities for her fourth observed teaching session, the activities for her writing instruction were designed at the level of the whole text. The exploration of the text structure was carried out through the presentation of texts in contexts, which were planned to be done in the Practice stage. These activities represent the modeling and deconstructing text activities in which teachers and students have the opportunity to examine the text structure and the linguistic features of the model text (Feez \& Joyce, 1998). After experiencing this text exploration, the students were provided with the last 
activity, which was Activity 5 in the Production stage, in which the students were required to individually write a birthday invitation with the context they personally created.

Another inconsistency was found in Nuri's implementation of the pre-, while-/ whilst-, and postspeaking stages. This inconsistency was related to the appropriateness of activities designed for the pre- and post-speaking stages to the characteristics of these stages. In the pre-speaking stage, Nuri did not prepare a particular activity in which the students were introduced to the new topic in the monologue recount that they were going to learn, to build up background knowledge, or to practice related vocabulary. Similarly, the postspeaking stage was not represented by any follow-up activity in which the students could link the follow-up activity to what they had learned in the previous stages.

In the case of implementing the text-based teaching and learning cycle for teaching receptive skills (listening and reading) and the productive skill (writing), the inconsistencies between theories and practices were reflected in both of the experienced and inexperienced teachers' instructional curriculum design. The inconsistency was centered around the practice that texts were not used as the departing point to conceptualize content and design activities. As Burns (2012) states, in text-based teaching, texts are central for conceptualizing content and designing activities. Accordingly, the design of instruction focuses on providing students with "knowledge and skills for understanding and engaging in extended texts used in real social contexts" (p. 140).

As exemplified in the cases of Meri and Tria, their conceptualizations encompassed two central points of skills and texts. The blend of these two content categories created tensions, as shown in Meri's and Tria's conceptualizations of PCK for organizing their learning activities within the text-based teaching and learning cycle. As a result, the designed activities in each stage of the teaching and learning cycle did not fully explore texts to help students engage with meaning in context, understand the language system realized in text, or interpret and respond to social communication occurring in texts (Feez \& Joyce, 1998). For example, in the stage of Building Knowledge of the Field, Tria prepared some general questions for teaching the listening skill and procedure in her first observed teaching session. In this stage, such general questions as, (1) What do you see in the video? (2) Can you make a fruit salad by yourself? (3) Is it easy or difficult for you to make fruit salad? and (4) How do you make fruit salad? were addressed to the students after they had watched the video on 'How to Make Fruit Salad,' in the stage of Building Knowledge of the Field. The above questions did not fully engage the students to investigate the social context of the model text, the social purpose of the text, and the immediate context of the situation by grasping the purpose, audience, language and structural features attached to the model text (Derewianka, 2003; Feez \& Joyce, 1998).
Another example in Tria's first teaching session was the design of a learning activity for the stage of Joint Construction of the Text. As Feez and Joyce (1998) suggest, at this stage, students start to be involved in the whole text construction while the teacher gradually reduces his/ her systematic assistance so as to enable students to take over their own text production. Instead of preparing an activity that matched the character of the Joint Construction of the Text stage, Tria designed a pair work activity in which the students were required to answer five multiplechoice questions for identifying various specific information after listening to the video on 'How to Make Fruit Salad.' This activity was mainly intended to develop particular micro listening skills, as elaborated in Tria's content conceptualization for her first observed teaching session. This kind of listening comprehension activity is obviously intended to transform the content representation of the target micro listening skills. It does not, however, provide the students with an opportunity to jointly construct the target procedure text.

These findings, related to conceptualizing content and organizing instruction, have, therefore, shown the participating teachers' knowledge deficiency of the textbased teaching and learning cycle. They also reveal the tensions inherent in the transformations of the 2006 SBC to instructional designs by teachers in the Indonesian EFL context. The presentation of texts, in this study, is done for the sake of developing particular micro and macro skills of English. By contrast, skills development in text-based teaching is carried out along with text exploration for meaning-making, that is, to engage students with language use and how this language use operates in its context (Burns, 2012; Feez \& Joyce, 1998). Teachers are, therefore, required to select essential micro and macro skills that students need in order to comprehend and/or compose texts. As such, the participating teachers' transformations of skills and texts do not fully represent the text-based pedagogy that characterized the 2006 SBC.

\section{CONCLUSION}

This study revealed the misunderstanding of the applied national EFL curriculum, which was called the 2006 School-based Curriculum (SBC) in the Indonesian EFL context. The findings of the study showed that texts are not ultimately used as the main starting point to design text-based instruction. The participating teachers' instructional design showcased a subtle mixture of the skill-based instruction, that focuses on the development of macro and micro language skills, and of text-based teaching, which requires teachers to teach texts as a meaning-making system. Such delicate mixture created a tension of focus, which resulted in practices in which the teachers insufficiently explored texts, while developing particular pre-specified micro and macro skills per se, and merely used texts as a means to develop the students' English language skills. As a result, the teachers' instructional curriculum design, as 
portrayed in this study, neither maximally developed macro and micro skills of English nor properly explored texts as regulated in the principles of text-based teaching.

The misconception is even worsened by the findings confirming the teachers' insufficient understanding of the organizing principles they adopted to sequence and organized their teaching and learning activities. As a result, inconsistencies between theory (the characteristics of the adopted organizing principles) and practice (the organization of the lessons) were found. The findings concerning the teachers' course organization confirm the complexity and intricacy of organizing mixed-content categories within particular organizing principles. As Graves (2000) states, this process is intricate since teachers have to make choices on what they have to include for their instruction, to frame what students really want to and have to learn in the designed instruction and to properly organize the adopted mixed-content categories in order to see the focus of the conceptualized content categories and the relation of each content category.

The findings of this study may also be potentially reflected in teachers' instructional design for implementing the current national EFL curriculum, the 2013 Curriculum. With the complex characteristics attached in the 2013 Curriculum (Kemendikbud, 2014), Indonesian EFL teachers are required to integrate more mandated content categories, in addition to texts and English language skills, such as values, 21st-century learning skills, and higher-order thinking skills, into their text-based instruction. Hence, teachers remain to face challenging tasks when they have to blend these varied content categories by following the prescribed scientific-based organizing principle.

Reflecting upon the findings and how they potentially become the challenges teachers encounter in teaching texts within the demand of the current Indonesian EFL curriculum, teachers need to be trained to make choices in the inclusion of varieties of content categories, to rationalize the relevance of the included content categories to student needs and learning objectives, and to organize the content categories within appropriate and relevant organizing principles. In order to properly practice text-based teaching, EFL teachers need to be equipped with theoretical and practical knowledge of implementing the methodology of textbased teaching. Teacher training programs, therefore, need to raise teachers' awareness to pay attention to the characteristics of any organizing principle they employ, and to match and to organize the teaching and learning activities within those characteristics.

\section{ACKNOWLEDGMENTS}

The author would like to express her gratitude to the Directorate General of Higher Education, Ministry of Research, Technology, and Higher Education, the Republic of Indonesia, Macquarie University, and Yogyakarta State University that supported the completion of the author's research.

\section{REFERENCES}

Albino, G. (2017). Improving readability in an explicit genre-based approach: The case of an EFL workplace context. RELC Journal,48(3), 311-326. doi: $10.1177 / 0033688216684279$

Burns, A. (2012). Text-based teaching. In Richards , J. C. \& Burns, A. (Eds.), The Cambridge guide to pedagogyand practice in second language teaching (pp. 140-148). NY, USA: Cambridge University Press.

Burns, A., Joyce, H. \& Gollin, S. (1996). I see what you mean'. Using spoken discourse in the classroom: A Handbook for teachers. Sydney: NCELTR

Cohen, L., Manion, L. \& Morrison, K. (2007). Research methods in Education (6th edn.). NY: Routledge.

Derewianka, B. (2003). Trends and is sues in genrebased approaches. RELC Journal, 34(2), 133-154. doi: $10.1177 / 003368820303400202$

Emilia, E. \& Hamied, F. A. (2015). Systemic functional linguistic genre pedagogy (SFL GP) in a tertiary EFL writing context in Indonesia. TEFLIN Journal, 26(2), 155-182. doi: 10.15639/teflin journal.v26i2/155-182

Feez, S. (1999). Text-based syllabus design. TESOL in Context,9(1), 11-14.

Feez, S. \& Joyce, H. (1998). Text-based syllabus design. NSW, Australia: Macquarie University.

Frankel, K. K. (2013). Revisiting the role of explicit genre instruction in the classroom. Journal of Education, 193(1), 17-30. doi: 10.1177/002205741319300103

Gibbons, P. (2015). Scaffolding language scaffolding learning: Teaching English language learners in the mainstream classroom (2nd edn.). Portsmouth, NH: Heinemann.

Graves, K. (2000). Designing language course. Boston: Heinle \& Heinle Publishers.

Graves, K. (2008). The language curriculum: A social contextual perspective. Language Teaching, 41(2), 147-181. doi: $10.1017 / \mathrm{s} 0261444807004867$

Halliday, M. A. K. (1975). Learning how to mean: Explorations in the development of language. London: Edward Arnold.

Hammond, J. \& Derewianka, B. (2001). Genre. In R. Carter \& D. Nunan (Eds.), The Cambridge guide to teaching English to speakers of other languages (pp. 194-200). New York: Cambridge University Press.

Hamzah \& Rozimela, Y. (2018). The use of scaffolding by English teachers at senior high school in West Sumatra, Lingua Didaktika, 12(1), 25-33. doi: 10.24036/ld.v 12i1.10195

Harmer, J. (2007). The practice of English language teaching. Harlow: Longman

Hyland, K. (2007). Genre pedagogy: Language, literacy and L2 writing instruction. Journal of Second Language Writing, 16(3), 148-164. doi: 10.1016/j.jslw.2007.07.005

Kemendikbud. (2014). Konsep dan implementasi 
Kurikulum 2013(The concept and implementation of Curriculum 2013) (PowerPoint slides).

Retrieved from

https://www.kemdikbud.go.id/kemdikbud/dokume n/Paparan/Paparan\%20W amendik.pdf.

Liang, E. (2015). Implementing genre-based curriculum cycle in teaching writing in a secondary school setting. Studies in Literature and Language, 10(1), 47-50.

Martin, J. R. (1999). Mentoring semogenes is: "Genrebased" literacy pedagogy. In F. Christie (Ed.), Pedagogy and the shaping of consciousness: Linguistic and social processes (pp. 123- 155). London: Cassell.

Martin, J. R. (2009). Genre and language learning: A social semiotic perspective. Linguistics and Education, 20, 10-21. 10.1016/j.linged.2009.01.003

Martin, J. R. (2013). Embedded literacy: Knowledge as meaning. Linguistics and Education, 24(1), 23-37. 10.1016/j.linged.2012.11.006

McDonough, J. \& Shaw, C. (2003). Materials and methods in ELT: A teacher's guide (2nd edn). Oxford, UK: Blackwell Publishing Ltd.

Megawati, F. \& Anugerahwati, M. (2012). Comic strips: A study on the teaching of writing narrative texts to Indonesian EFL students. TEFLIN Journal, 23(2), 183-205.

Miles, M. B., Huberman, A. M. \& Saldana, J. (2014). Qualitative data analysis: A methods sourcebook (3rd edn.). CA: Sage Publications, Inc.

Mishan, F. (2005). Designing authenticity into language learning materials. Bristol, UK: Intellect Ltd.

Patton, M. Q. (2002). Qualitative research \& evaluation methods (3rd edn.). CA: Sage Publications, Inc.

Ramos, K. A. (2015). Using genre pedagogy to teach adolescent English learners to write academic persuasive essays. The Journal of Education, 195(2), 19-35. doi: 10.1177/002205741519500205
Ranker, J. (2009). Learning nonfiction in an ESL class: The interaction of situated practice and teacher scaffolding in a genre study. The Reading Teacher, 62(7), 580-589. doi: 10.1598/rt.62.7.4

Rivera, J. D. H. (2012). Using a genre-based approach to promote oral communication in the Colombian English class room. Colombian Applied Linguistics Journal, 14(2), 109-126. doi: 10.14483/udistrital.jour.calj.2012.2.a07

Rose, D. (2011). Beyond literacy: Building an integrated pedagogic genre. Australian Journal of Language and Literacy, 34(1), 81-97.

Saldana, J. (2013). The coding manual for qualitative researchers. London: Sage Publications, Inc.

Shulman, L. (1987). Knowledge and teaching: Foundations of the new reform. Harvard Educational Review, 57(1), 1-22. doi: 10.17763/haer.57.1.j463w79r56455411

Stake, R. E. (2006). Multiple case study analysis. NY: the Guilford Press.

Spratt, M., Pulverness, A. \& Williams, M. (2005). The TKT (Teaching Knowledge Test) Course. Cambridge: Cambridge University Press.

Thai, M. D. (2009). Text-based language teaching. NSW: Mazmania Press.

Tomlinson, B. (2012). Materials development for language learning and teaching. Language Teaching, 45(2), 143-179. doi: $10.1017 / \mathrm{s} 0261444811000528$

Widdowson, H. G. (1998). Context, community and authentic language. TESOL Quarterly, 32(4), 705716. doi: $10.2307 / 3588001$

Yasuda, S. (2011). Genre-based tasks in foreign language writing: Developing writers' genre awareness, linguistic knowledge, and writing competence. Journal of Second Language Writing , 20(2), 111-133. doi: 10.1016/j.jslw.2011.03.001

Yin, R. K. (2014). Case study research: Design and methods (5th edn.). CA: Sage Publications, Inc. 